\title{
The Influence of IAS/IFRS on the New OHADA General Chart of Accounts
}

\author{
Ivan Djossa Tchokote \\ Catholic University of Central Africa, Yaoundé, Cameroon
}

\begin{abstract}
Accounting standardization in black African French-speaking countries is presented through two streams of research. The first stream presents the general chart of accounts common to all these countries as an accounting model which reconciles the divergences between the Anglo-Saxon and continental approaches to accounting, and thereby satisfies the requirements of users of accounting information. The second stream considers that the convergence towards IAS/IFRS is a vital way of attracting international investors and increasing development. This article stands by the second perspective and analyzes the changes introduced in the PCG-OHADA (2017) compared to the PCG-OHADA (2000). It shows that the new provisions of the PCG-OHADA are mainly inspired by IAS 1, IAS 16, IAS 19, IAS 36, IAS 38, IAS 40, and IFRS 6.
\end{abstract}

Keywords: OHADA, IFRS, PCG, accounting standards, accounting harmonization

The OHADA General chart of accounts (PCG-OHADA) was adopted in November 2000 by black African French-speaking countries of the West African Monetary and Economic Union (UEMOA) and Central African Economic and Monetary Community (CEMAC) regions, in order to harmonize accounting practices and to improve the business environment in Africa. It was conceived as an intermediary model between the two major accounting models ${ }^{1}$ to meet the needs of users of accounting information in French-speaking black Africa (Colasse, 2009).

Facing the lack of governance in Organization for the Harmonization of Business Law in Africa (OHADA) institutions and the poor organization of the accounting profession in the OHADA environment (Klutsch \& Nguéma, 2010), it is only after 17 years that the PCG-OHADA was revised. Indeed, the new PCG-OHADA was adopted on the 15th of February 2017, before its enforcement on the 1st of January, 2018 for personal entities. This new PCG-OHADA, although faithful to the principles of the European-Continental School, confirms the approach of its predecessor, namely: the opening towards the principles of the Anglo-Saxon school. Nevertheless, it distinguishes itself from the latter by the adoption of new accounting valuation standards and presentation of financial statements, inspired by IAS/IFRS.

This evolution in accounting standards in French-speaking Africa deserves more academic attention. Indeed the problem of harmonization between accounting standards already in force in the OHADA environment and the International Accounting Standards (IAS)/International Financial Reporting Standards (IFRS) hits the very essence of all debates. While some authors continue to see the PGC-OHADA as an

\footnotetext{
Ivan Djossa Tchokote, Ph.D. in Management Science, lecturer; director of the Accounting and Finance Masters' Course, Department of Economics, Management and Information Systems, Catholic University of Central Africa, Yaoundé, Cameroon.

1 The partnership model of the European-continental school and the Shareholder value model of the Anglo-Saxon.
} 
accounting model which reconciles the schools of European-continental and Anglo-Saxon accounting (Gouadain, 2000; Bijou-Laré, 2004; Colasse, 2009; Causse, 2009; Degos \& Souleymanou, 2017), others believe that the convergence ${ }^{2}$ from the PCG-OHADA to IAS/IFRS is a necessity (Klutsch \& Nguéma, 2010; Feudjo, 2010; Ngantchou, 2011). This study contributes to this reflection, with the objective of presenting the accounting changes and innovations in the PCG-OHADA (2017) that could be attributed to IAS/IFRS.

\section{The Origin of Accounting Revisions in the OHADA Environment}

Accounting reforms in the OHADA environment cannot be dissociated from the changes that occurred at the end of the 1980s. Indeed, the confrontation between the capitalist model and the socialist model prevailing at the time of the Cold War is replaced by a trend of globalization whose effects have not been neutral on the international accounting standardization process (Gouadain \& Wade, 2009). With regards to this, the necessity to update the accounting framework in French-speaking black Africa appeared as an emergency for its opening up to the international scale. Given the shortcomings of the OCAM accounting plan adopted from the start of the 1970s by the majority of countries of the CEMAC and UEMOA regions, the adoption of the PCG-OHADA was de facto, part of the integration of the different approaches of the Anglo-Saxon model and the continental model (Gouadain \& Wade, 2009).

\section{The Shortcomings of the OCAM Accounting Plan}

At the beginning of the 1960s, when most of the countries of the current OHADA environment gained political independence, it became necessary to adopt an accounting framework that could meet their information needs. $^{3}$ The needs are first macroeconomic in an environment where the Keynesian model appears as a salutary approach to a problem of development (Ngantchou, 2011). Private accounting was then supposed to provide data necessary for the computation of basic aggregates of national accounts. The issues relating to the adoption of an accounting framework after the independence of these countries are then of a microeconomic order, given the fragility of nascent companies, which do not yet have a formalized information system for decision-making (Ngantchou, 2011). Thus, in 1968, through the initiative of the head of states of French-speaking Africa, a commission of African and French experts met at Niamey, and proposed the African and Malagasy Common Organization (OCAM) accounting plan.

The existence of a common chart of accounts did not, however, reduce the implementation divergences from one country to the other. Hence, rather than leading to harmonized accounting practices in all the countries that had adopted it, the implementation of the OCAM chart of accounts resulted in a "cover-up unit", because in facts, we witnessed an intensification of divergences (Péronchon, 2009). This inability of the OCAM accounting plan to achieve a convincing result in terms of harmonization can, to some extent, be justified by the international political and economic context of that time, which was dominated by the dualism opposing capitalism and socialism or what amounts to the same, between the market and the state (Ngantchou, 2011).

In a context in which the state was supposed to play an active role in the economy, and especially in the absence of local expertise, an accounting model based on a framework seemed indeed appropriate for countries in

\footnotetext{
2 The word convergence implies the reconciliation between the two systems through the means of an exchange of concepts and techniques. In this particular case, we speak of a reconciliation between PCG-OHADA and the IAS/IFRS by means of the adoption of IAS/IFRS in the PCG-OHADA, which is defined by some people as an alignment.

${ }^{3}$ Until 1960, the principal frame of reference applicable by black African French-speaking countries was the 1947-1957 accounting plan in force in France.
} 
need of development (Causse, 2009). At the same time, however, there was a need to adapt the accounting system to the needs of companies operating in a competitive environment. The reconciliation of these two objectives is a real challenge (Causse, 2009). Indeed, at a time when the accounting reform of OCAM is envisaged, the accounting environment of the countries of French-speaking Africa presents many challenges that can be circumscribed to two major issues: that of the harmonization of accounting practices to the regional scale, and that of the opening to dominant accounting models (Gouadain \& Wade, 2009). The reform could not do without the need to align the accounting framework with the progress being made in the countries of the European Union.

\section{The Influence of European Accounting Harmonization}

The influencing relationship between the dynamics of European accounting harmonization and accounting harmonization in French-speaking black Africa is not a one-way, center-periphery relationship, but a relationship of reciprocal dependence (Pérochon, 2009). Even though the OCAM chart of accounts generally served as a preparatory framework for accounting standardization throughout the French-speaking region, it should be noted that the arguments for this investigation were sometimes provided by requirements related to European accounting harmonization, at a time when the latter itself was facing the onslaught of Anglo-Saxon accounting standards (Colasse, 2004).

For instance, the French Accounting Plan of 1982 (PCG, 1982) results from the adoption of the 4th EU directive. This directive first introduces the concept of true and fair view, which it considers as an objective assigned to the annual accounts. It also introduces "notes to the accounts" as part of the annual accounts of companies. The 7th EU directive adopted in 1983 expands the 4th directive to entities constituted in the form of groups, circumscribing the scope of consolidation and defining the methods of consolidation of accounts.

The introduction of the 4th and the 7th EU directive in France will result in restarting the process of accounting harmonization between France and Black Africa. On 17 October 1993 at the Summit in Port Louis (Mauritius), this common political will lead to the signing of the Organization for the Harmonization of Business Law in Africa (OHADA) Treaty. Following the signature of this, treaty, the West African Economic and Monetary Union (WAEMU) countries will abandon the OCAM chart of accounts to create their own chart of accounts. This new accounting plan, strongly inspired by PCG 1982 and the Anglo-Saxon practice, was named West African Accounting System (SYSCOA) and adopted on 1st January 1998. Ultimately, OCAM will be totally undermined with the adoption of the uniform act on the organization and harmonization of company accounts, and the entry into force of the OHADA Accounting System in 2001 for personal accounts, and in 2002 for consolidated accounts (Feudjo, 2010).

The OHADA accounting model is with a leg on each side of the international and continental logic. This model is part of a differential economic context including the major economic groupings of the world and the desire to harmonize the language of business.

\section{The Main Features of the OHADA Accounting Model}

As of February 15, 2017, accounting regulations in the OHADA region are now based on the Uniform Act on Accounting Law and Financial Reporting, and no longer on the Uniform Act on the Organization and Harmonization of Company Accounts, adopted in 2000. The OHADA accounting system, which comprises the OHADA General chart of accounts (PCG-OHADA) and an accounting system for consolidated and combined accounts, is joint to this uniform act. The PCG-OHADA (2017) follows the approach of his predecessor and replicates the key benefits provided to stakeholders. 


\section{Respect for Continental Europe Principles}

According to Gouadain (2000), in order to assess the conformity of the PCG-OHADA with the principles of the continental model in terms of standardization, it is necessary to consider the following three characteristics: the objectives in terms of the party receiving the information, the identity of the standardization actors, and the scope covered by the recommendations which it makes.

Recipients of accounting information. In the PCG-OHADA (2017), just as in the PCG-OHADA (2000), the accounting information is placed under the sign of "shared relevance". It must meet the needs not only of investors but of several categories of users, and allow each party to make important decisions.

The PCG-OHADA (2017) specifies that financial statements constitute the main means of communication of financial information to various users, internal and external to the entity, which are:

- Managers, the administrative and control bodies with various internal structures of the entity;

- Providers of capital (investors, banks and other lenders, issuing institutions and other lenders);

- The state, the Balance Sheet center and other institutions vested with planning, regulatory and control powers;

- Other partners of the entity, such as insurers, employees, suppliers, or customers;

- Other interest groups, including the general public.

With regards to recipients of accounting information, the PCG-OHADA (2017) is in favor of the continental design of accounting.

Standardization actors. There is no doubt that the PCG-OHADA (2017) remains a standard of public initiative, written with the initiative or under the auspices of public authorities, by a body specially created, and composed in such a way that all stakeholders can be heard (Gouadain, 2000).

The OHADA Accounting Standardization Committee (CNC-OHADA) established by Regulation No.002/2009/CM/OHADA had indeed held its first general assembly on 27 and 28 October 2009. Klutsch and Nguéma (2010) then called on it to speed up the pace of work on the following points:

- The adoption or not of full IFRS for listed companies;

- The detailed comparative analysis of the IFRS SME standards and those of the OHADA;

- The accounting standardization process and the management of reactivity constraints;

- The coexistence and the respective role of CEMAC/UEMOA accounting institutions.

The Scope and methods of standardization. With regards to the scope and methods of standardization, the PCG-OHADA (2017) is very much in line with the concept of chart of accounts as in the continental European tradition. Indeed it has detailed the accounting scheme that company's need to implement, and is particularly concerned with guiding them through the following mechanisms:

- The list of terms;

- The structure, content, and operation of accounts;

- Valuation rules;

- Rules for the presentation of the financial statements;

- Methods of consolidation and combination of accounts.

In comparison with the PCG-OHADA (2000), there is no particular development to highlight, except for an application guide that presents the accounting entries in relation to:

- Current operations; 
- Operations and specific problems;

- The presentation of the annual financial statements;

- Consolidated and combined accounts.

\section{The Accommodation of Certain Accounting Innovations}

Some innovations introduced by the PCG-OHADA (2000) have been reviewed by the PCG-OHADA (2017), while others have simply been deleted.

Modulated information. Inspired by the French Accounting Plan of 1982, PCG-OHADA (2000) chooses to "adjust" accounting requirements, particularly with regards to the presentation of financial statements, by proposing to differentiate between three "systems", depending on the size criteria: a normal system, a lightened system, and a minimum cash system (Gouadain, 2000).

The PCG-OHADA (2017) eliminates the lightened system and maintains the normal system and the minimum cash system. According to Article 11 of the Uniform Act on Accounting Law and Financial Reporting (AUDCIF), "the presentations of annual financial statements and bookkeeping follow the normal system and the minimal Cash system. Every entity, except for its size, is subject to the normal system of presentation of financial statements and bookkeeping”.

Article 26 of the AUDCIF states that

the normal system includes the preparation of the Balance Sheet, the Income Statement for the financial year, the Cash Flow Statement as well as the Notes to the Financial Statements, and the minimum cash system rests on the preparation of a Balance Sheet, a Statement of Income and Notes attached drawn from cash accounting.

More complete financial information. In this respect, the PCG-OHADA (2000) makes the following contributions (Gouadain, 2000):

- The renewal of possibilities for economic and financial analysis, thanks to a refinement of notions of value added and gross operating surplus;

- A greater facility for calculating cash flow;

- The introduction of the Resource and Employment Financing Table (TAFIRE);

- The appearance of the annexed statement, which was added to the basic financial documents.

The PCG-OHADA (2017) makes some modifications to the calculation of the commercial margin and value added.

In fact, when it is unable to relate supplementary expenses to each category of goods purchased (customs, freight, insurance, commissions, brokerage, transit fees, transport, and other incidental expenses), the entity may create "purchases" sub-accounts, whereas previously, it had to use a "transport" or "service" sub-account. The cost of goods sold during a fiscal year is therefore equal to the cost of buying the goods during the same period, less or increased by the change in inventory. Similarly, the sub-account "operating expenses transfer" is now included in the calculation of value added, while previously it was included for the calculation of operating income.

Ultimately, the PCG-OHADA (2017) eliminates the TAFIRE which it replaces with the Cash Flow Statement and transforms the annexed statement notes attached to financial statements. According to Article 8 of the AUDCIF, "a complete set of annual financial statements include the Balance Sheet, the Income Statement, Cash Flows statement and the Notes to financial statements".

The economic perception of accounting. The PCG-OHADA (2000) introduces the principle of substance over form, but retained no less than five applications: 
- The capitalization of property held with "retention of title";

- The capitalization of the assets made available to the concessionaire by the grantor;

- The capitalization of assets under a financial lease by the user of the said assets;

- The entry on the assets side of bills discounted not yet due or honored;

- The inclusion in staff costs of staff costs invoiced by other companies.

The PCG-OHADA (2017) approves this choice, and recognizes the principle of substance over form, which is referred to as a postulate.

\section{The Expansion of Accounting Information in the PCG-OHADA}

The evolution of the accounting system in French-speaking Africa is linked to the evolution of accounting standards and practices in continental Europe and more particularly in France (Feudjo, 2010). However, the economic weight of countries that have adopted IFRS is also one of the foundations of accounting standard setting in French-speaking Africa. The accounting system being an economic challenge, the countries of the OHADA region are now faced with the obligation of allowing the comparability of accounts on an international scale, in order to satisfy investors.

\section{The Use of Accounting Principles}

Regulatory provisions of PCG-OHADA (2000) enclose all the principles recognized and applied by IFRS. However, there were significant differences in the application of some important principles. Our analysis is limited to the study of accounting principles, assets and liabilities, and financial statements.

Historical cost to fair value. The PCG-OHADA (2000) has made obligatory the respect for the historical cost principle as the basis for the accounting measurement of results and asset valuation. The IASB has made its application optional by replacing it with the concept of fair value. It refers to any asset, either its price on the market or its exchange value, or the present value of future benefits it may bring to the company (Feudjo, 2010).

Henceforth, the PCG-OHADA (2017) mandates the practice of asset impairment in accordance with IAS 36 "Impairment of Assets". The business must assess whether there is any indication that an asset has been impaired at the end of the year. If there is such an index, the entity must estimate the present value of the asset concerned and compare it to its net book value. If its present value is lower than its net book value, the asset should be depreciated in the accounts.

Capital gains arising from this estimate are not recognized. On the other hand, the losses are recorded in the depreciation account.

The prudence principle. The prudence concept is allowed both in the PCG-OHADA as well as in IFRS. In the PCG-OHADA (2000), however, its application revealed significant differences. In fact, the amortization of intangible assets was not systematic. Items whose depreciation value was not determined a priori were not subject to any amortization (Trade marks, patents, licences, goodwill, etc.) (Feudjo, 2010).

In PCG-OHADA (2017), amortization of intangible assets is now mandatory. Patents are depreciable over the term of protection they enjoy, or over their actual duration of use. Licenses are amortized over their probable useful life, which cannot exceed the duration of the authorization, after which the residual value will be nil. Trademarks are depreciable over the period of consumption of the expected economic benefits of the mark, except for those subject to legal protection, which remains non-depreciable.

These provisions comply with those of IAS 38 "Intangible Assets" which advocates systematic amortization 
of all intangible assets with a maximum life of 20 years. The observation we can make about the prudence concept is clear. The prudence concept is now applicable in the PCG-OHADA as recommended by IFRS.

\section{The Presentation of Financial Statements}

The annual financial statements of normal system in the PCG-OHADA (2017) include the Balance Sheet, the Income Statement, the Cash Flow Statement, and the Notes to the Financial Statements. Our analysis of the influence of IAS/IFRS does not address the Notes.

The capitalization of assets. In the PCG-OHADA (2017), an asset is now defined as an identifiable element representing a current economic resource controlled by the entity as a result of past events. It is included in the Balance Sheet when it is probable that the entity will benefit economically from it, and the asset has a cost or value that can be measured reliably. This implementation of IAS 1, in PCG-OHADA, results in the adoption of new provisions based on IFRS, pertaining to intangible and tangible assets.

Inspired by IAS 38, the PCG-OHADA (2017) makes the recognition of the following intangible assets mandatory:

- Costs incurred for the acquisition of customer files, notices, titles of newspapers and magazines, and websites;

- Costs incurred for obtaining contracts;

- Costs incurred for the acquisition of specific skills for personnel;

- Exploration and exploitation costs of mineral resources (IFRS 6).

Inspired by IAS 16, the PCG-OHADA (2017) makes the recognition of the following as items of property, plant, and equipment mandatory:

- Capitalized asset components and their structures;

- The cost of inspection or major revisions;

- Investment properties (IAS 40).

These new provisions of the PCG-OHADA, which concern intangible and tangible fixed assets, correspond to the implementation of IAS 1, IAS 16, IAS 40, and IFRS 6. This change in OHADA accounting standards towards IFRS, confirms a little more the alignment of PCG-OHADA to IFRS.

Provisions. Similarly, in the PCG-OHADA (2017), a liability is recognized in the Balance Sheet when it is probable that a transfer of economic resources will result from the settlement of the obligation borne by the entity, and the amount of this settlement can be measured reliably.

It is recognized in the Balance Sheet when it is probable that a transfer of economic resources will result from the settlement of the obligation borne by the entity, and that the amount of this settlement can be measured reliably. The outcome of this implementation of IAS 1, in the PCG-OHADA (2017), is the adoption of new rules based on IFRS, pertaining to provisions.

By implementing IAS 19 “Employee Benefits”, the new PCG-OHADA makes the recognition of provisions for pensions and similar obligations mandatory.

In addition, the cost of dismantling, removing, and rehabilitating the site must now be provisioned in accordance with IAS $16^{4}$.

\footnotetext{
${ }^{4}$ This accounting concept has been transposed in the general chart of accounts applicable to individual accounts of French companies, as a liability by law of the Accounting Regulation Committee (CRC) No.2000-06 of 7 December 2000, and as an asset by law CRC No.2004-06 of 23 November 2004.
} 
Revenue from operating activities. According to the PCG-OHADA (2017), revenue from operating activities is recognized when an increase in the economic benefits, related to an asset enhancement or a decrease in liability, has occurred and can be measured reliable.

This implementation of IAS 1 results in the adoption of new provisions relating to revenue from ordinary activities.

By the implementation of IFRS 15, the PCG-OHADA (2017) recommends the application of the percentage-of-completion method or completion method for the accounting treatment of a construction contract.

Cash Flow Statement. In the PCG-OHADA (2000), the Income Statement took precedence with principles, such as the matching of expenses to revenue, accruals, the spread of the recognition of certain expenses (pensions, foreign exchange differences, and deferred charges). For PCG-OHADA (2017), priority is given to the Cash Flow Statement.

The PCG-OHADA (2017) introduces the Cash Flow Statement, among the financial statements to be presented by the companies, replacing the TAFIRE. This provision complies with IAS 7, which makes the presentation of cash flows for the year subject to the nature of the activity (operational, investment, and financing).

Consolidated financial statements. Prior to the revision of the OHADA Uniform Act, dominant companies in the OHADA region formed by states-parties of the region, which were themselves under the control of another company in the same region subject to an obligation of consolidation, were exempted from the preparation and publication of consolidated financial statements. The New OHADA Uniform Act introduces the obligation to present consolidated financial statements according to IFRS ${ }^{5}$. Article 75 of the Uniform Act on Accounting and Financial Reporting (AUDCIF) states that "the consolidated financial statements of entities whose securities are listed on a stock exchange and those seeking funding in connection with a public offering shall be prepared and presented according to IFRS”.

For the purpose of this article on the presentation of financial statements under IFRS, we can finally conclude that the similarities between the OHADA and international standards are numerous. It is therefore possible to say that the OHADA accounting standard setter has succeeded in building a conceptual framework in harmony with that which is internationally renowned (Degos \& Souleymanou, 2017).

\section{Conclusion}

The new provisions introduced by the PCG-OHADA (2017) are essentially inspired by IFRS. They mainly concern the practice of impairment testing of assets in accordance with IAS 36 "Impairment of Assets", the mandatory amortization of intangible assets in accordance with IAS 38 "Intangible Assets", the recognition of a assets in the Balance Sheet when it is probable that economic benefits will flow to the entity and the asset has a cost or value that can be measured reliably, and the recognition of a liabilities in the Balance Sheet when it is probable that a transfer of economic resources will result from the settlement of the obligation borne by the entity and that the amount of this settlement can be measured reliably.

This reform therefore entails the adoption in the PCG-OHADA, of "fair value" as opposed to historical cost, of the principle of economic substance over the legal form, of new assets and liabilities, and the cash flows statement at the detriment of TAFIRE. The adoption of these new standards that we have just analyzed, from the

\footnotetext{
${ }^{5}$ See Appendix 1, a tabular comparison of the OHADA uniform acts of the year 2000 and 2017, proposed by Degos and Souleymanou (2017, pp. 22-23).
} 
Anglo-Saxon school, shows that the standardization process in the OHADA region is now under a strong influence of the international accounting standardization process. Faced with the increasing weight of IFRS worldwide, the importance of international groups in the economies of the OHADA region, but also the lack of governance and organization of the accounting profession in the OHADA region, the PCG-OHADA tends consequently to progressively align with IFRS.

However, while IFRS have been designed primarily for large companies, the PCG-OHADA is aimed at all types of companies, with a variable level of requirements depending on the size of the company. In this perspective, should the PCG-OHADA not proceed towards the maintenance of a double accounting system, as is the case in the Anglo-Saxon countries, at the risk of depriving the countries of the possibility to implement their own tax strategies (Degos \& Souleymanou, 2017).

\section{References}

Bigou-Lare, N. (2004). Le SYSCOA, vers des normes comptables uniformes dans l'UEMOA? Une analyse de la pratique togolaise. Comptabilité-Contrôle-Audit, 10(1), 63-78.

Causse, G. (1999). Vingt ans de normalisation comptable et de PCG: Son influence dans les pays d'Afrique francophone. Comptabilité-Contrôle-Audit, 5, 211-222.

Causse, G. (2009). Développement et comptabilité. In B. Colasse (dir), Encyclopédie de Comptabilité, Contrôle de gestion et Audit (pp. 689-704). Paris: Economica.

Colasse, B. (2004). Harmonisation comptable internationale: De la résistible ascension de l'IASC/IASB. Gérer et Comprendre, (75), 30-40.

Colasse, B. (2009). Le Sycoa-OHADA à l'heure des IFRS. Revue Française de Comptabilité, 425, 25-29.

Degos, J. G., \& Souleymanou, K. (2018). Révision de l'acte uniforme SYSCOHADA: À l'heure de l'adoption des normes IFRS dans les structures informelles des états parties? Revue du FINANCIER, 228-229(39-40), 50-73.

Dicko, S., \& Fortin A. (2014). IFRS adoption and the opinion of OHADA accountants. Afro-Asian J. Finance and Accounting, 4(2), 141-162.

Djossa I. (2019). Les principals mutations et nouveautés du plan comptable general OHADA. Yaoundé: Presse de l’UCAC.

Djossa, I. (2011). La diffusion du Système comptable OHADA auprès des PME camerounaises: Un processus inachevé. Gérer et Décider: (3), 113-130.

Elad, C. (1996). Implementing the OCAM plan: Two contrasting cases. Advance in International Accounting, 9, 47-72.

Elad, C. (2015). The development of accounting in the franc zone countries in Africa. The International Journal of Accounting, 50(1), 75-100.

Feudjo, J. R. (2010). Harmonisation des normes africaines (OHADA) et internationales (IAS/IFRS): Une urgence ou une exigence? La Revue des Sciences de Gestion, (245-246), 149-158.

Gouadain D., \& Wade, B. (2009). Syscoa/Ohada. In B. Colasse (dir.), Encyclopédie de comptabilité, contrôle de gestion et audit (pp. 1301-1316). Paris: Economica.

Gouadain, D. (2000). Le Syscoa, ce méconnu. Comptabilité-Contrôle-Audit, 6(1), 85-99.

Hoarau, C. (1995). L'harmonisation comptable internationale: Vers la reconnaissance mutuelle normative? Comptabilité-Contrôle-Audit, 1(2), 75-88.

Klutsch, S., \& Nguéma, Y. P. (2010). Quel avenir pour le droit comptable OHADA. Revue Française de Comptabilité, 432, 49-53.

Ngantchou, A. (2011). Le Système Comptable OHADA: Une réconciliation des modèles européen continental et anglo-saxon? Comptabilité-Contrôle-Audit, 17(3), 31-54.

PCG-OHADA. (2000). Acte Uniforme Relatif au droit comptable. Journal Officiel de l'OHADA, (10), 443.

PCG-OHADA. (2017) Acte Uniforme Relatif au droit comptable et à l'information financière et système comptable OHADA. Journal Officiel de l'OHADA, (Special), 1242.

Pérochon C. (2009). Normalisation comptable francophone. In B. Colasse (dir.), Encyclopédie de comptabilité, contrôle de gestion et audit (pp. 1081-1095). Paris: Economica. 
Appendix 1: Comparison of the Uniform Act of November 20th, 2000 and the Uniform Act of February 15, 2017

\begin{tabular}{|c|c|c|c|}
\hline & Amendments at the level of & Uniform Act 2000 & Uniform Act 2017 \\
\hline 1 & The rationale & Favors the harmonization of accounting systems for companies & Favors the standardization of Accounting and Financial reporting. \\
\hline 2 & $\begin{array}{l}\text { Accounting conventions, } \\
\text { and principles }\end{array}$ & $\begin{array}{l}\text { The eight accounting principles: prudence (Articles } 3 \text { and 6), } \\
\text { transparency (Articles 6, 8, 9, 10, and 11), significant importance } \\
\text { (Article 33), intangibility of the exercise Balance Sheet (Article 34), } \\
\text { historic cost (Articles } 35 \text { and 36), going concern (Article 39), } \\
\text { permanence of methods (Article 40), and specialization of } \\
\text { exercises (Article 59). }\end{array}$ & $\begin{array}{l}\text { The eight accounting principles of the uniform act of the year } 2000 \\
\text { recycled. But other accounting conventions can be listed: entity } \\
\text { convention, monetary unit, periodicity (Article 17), the realization of } \\
\text { revenue, matching revenue to expenses, objectivity, full disclosure } \\
\text { of information, the pre-eminence of substance over form (Articles } \\
35 \text { and 36). }\end{array}$ \\
\hline 3 & The conceptual framework & $\begin{array}{l}\text { Satisfy the requirements of faithfulness and sincerity in order to } \\
\text { ensure the authenticity of accounting entries in such a way that } \\
\text { accounting may serve as an instrument to measure the rights and } \\
\text { obligations of company stakeholder's, also as an instrument of } \\
\text { proof for third parties and management (Article 14). }\end{array}$ & $\begin{array}{l}\text { Constitute a general framework for the elaboration of new standards, } \\
\text { arbitrate between two standards whenever there are divergences, } \\
\text { interpret financial statements and resolve accounting questions } \\
\text { which are not treated by the standards, assist those preparing } \\
\text { financial statements in using accounting standards (Article 14). }\end{array}$ \\
\hline 4 & $\begin{array}{l}\text { Communication mechanism } \\
\text { of financial statements }\end{array}$ & Balance Sheet, Income Statement, TAFIRE, annexed statement. & $\begin{array}{l}\text { Balance Sheet, Income Statement, Statement of changes in equity, } \\
\text { Cash Flow Statement, note to the accounts, other information } \\
\end{array}$ \\
\hline 5 & Use of financial statements & $\begin{array}{l}\text { OHADA distinguishes internal users from external users. Internal } \\
\text { users are: management, administrative bodies and other internal } \\
\text { structures of the company. External users are: Providers of capital } \\
\text { which are investors, lenders and those who grant subventions, the } \\
\text { administration, and other institutions. }\end{array}$ & $\begin{array}{l}\text { OHADA considers investors as the privileged users of financial } \\
\text { statements by answering to the needs of the latter who has limited } \\
\text { sources of information and funding. It automatically satisfies the } \\
\text { needs of other users. }\end{array}$ \\
\hline 6 & $\begin{array}{l}\text { Objectives of annual } \\
\text { accounts }\end{array}$ & $\begin{array}{l}\text { OHADA distinguishes many objectives for financial statements. } \\
\text { The first objective is to make available useful information for } \\
\text { decision making and credit. The second, is to provide information } \\
\text { in order to estimate the probability that future inflows will occur. } \\
\text { Finally, to give information on the financial position of the } \\
\text { company particularly on the resources which she controls and her } \\
\text { obligations ; make available information on the financial } \\
\text { performance of the company; provide information on how the } \\
\text { company obtains and spends its liquidity; provide information on } \\
\text { the degree of realization of the objectives of management and the } \\
\text { degree of conformity to the laws in force }\end{array}$ & $\begin{array}{l}\text { For the OHADA just as for the IASB, the general objective of } \\
\text { financial statements first and foremost consists in providing } \\
\text { information on the financial position of the company and its } \\
\text { evolution, which is shown in the Balance Sheet. Secondly, provide } \\
\text { information on company performance particularly on its } \\
\text { profitability. Thirdly, make available information on the changes in } \\
\text { the financial situation of the company while showing if she can } \\
\text { generate enough liquidity since this permits to appreciate } \\
\text { investment, financing and operating activities within the financial } \\
\text { year. }\end{array}$ \\
\hline 7 & $\begin{array}{l}\text { Characteristics of the } \\
\text { information }\end{array}$ & Communication of accounting information & Communication of financial information \\
\hline 8 & $\begin{array}{l}\text { Presentation of financial } \\
\text { statements }\end{array}$ & $\begin{array}{l}\text { Normal system, the lightened system and the minimum cash } \\
\text { system }\end{array}$ & $\begin{array}{l}\text { Normal system, the minimum cash system, IFRS financial } \\
\text { statements }\end{array}$ \\
\hline
\end{tabular}

